\title{
Diabetic Foot Salvage by Limited Access Dressing (LAD)
}

Pramod Kumar

Consultant Plastic Surgeon, King Abdulaziz Specialist Hospital, Sakaka, Al Jouf Health Affair, MOH, Saudi Arabia

Corresponding author: Pramod Kumar, Consultant Plastic Surgeon, King AbdulAziz Specialist Hospital, Sakaka, Al Jouf Health Affair, MOH, Saudi Arabia, Tel: +966551521514/+919901700052; E-mail: pkumar86@hotmail.com

Rec date: Mar 31, 2014, Acc date: Apr 26, 2014, Pub date: Apr 29, 2014

Copyright:@ 2014 Kumar $\mathrm{P}$, et al. This is an open-access article distributed under the terms of the Creative Commons Attribution License, which permits unrestricted use, distribution, and reproduction in any medium, provided the original author and source are credited.

\begin{abstract}
Moist wound healing and Negative pressure wound therapy (NPWT) are newer concepts in wound management. NPWT has been shown to be a safe and effective treatment for complex diabetic foot wounds. Limited Access Dressing (LAD) combines the principles of moist wound healing and NPWT along with a provision of two additional ports (1216Frtube) for instilling antimicrobial solution of choice and alters the wound environment without any need to change the dressing. LAD utilizes definite intermittent negative pressure schedule (30 minutes of negative suction and $3 \frac{1}{2}$ hours of rest period; minimum $30 \mathrm{mmHg}$ of negative pressure). Intermittent negative pressure regimen of LAD reduces the total duration of negative pressure and need for specially designed suction devices. The LAD design has notable advantages, while avoiding some major disadvantages such as an inaccessible offensive smelling wound environment and relatively high treatment cost.
\end{abstract}

Neuropathy, angiopathy, skin changes (cracks), callosities, and foot deformities leads to nonhealing ulcers followed by infection. Non healing ulcers and infection are major reasons for progressive tissue destruction in diabetic patients. Repeated radical debridement leads to loss of certain amount of viable tissue exposing vital structures, bone, ligaments and subsequent desiccation of exposed tissues and infection starts avicious cycle of debridement and further tissue destruction leading to amputation. LAD has been proved to control wound infection, and help in separation of dead tissue from living tissue by autolytic and mechanical debridement while preserving viable tissue as compared to that by surgical debridement.

By virtue of better control of infection and systemic inflammatory response syndrome (SIRS), early physiotherapy (minimizing stiffness and deformity), advantages over other modern methods of dressings and ultra conservative debridement (minimal damage to viable tissue by safer intra LAD natural separation of necrotic tissue), LAD acts as a reliable and effective method of limb salvage in diabetic patients.

\section{Introduction}

Forty five percent of all lower limb amputations (LLA) are performed on patients with diabetes. Diabetes related amputation rates increase with age and are higher in males. Overall, diabetic personshave a 15 times higher risk of LLA than nondiabetic individuals [1]. From a public health standpoint, diabetes related amputations are now more common than those resulting from exploding hidden landmines, leading to $70 \%$ of the lower extremity amputations around the world [2]. Diabetes around the globe results in one major limb amputation every 30 seconds, over 2500 limbs lost per day! In India alone, 40,000 amputations are performed annually $[3,4]$.

Arterial problems in diabetes producing gangrene are also a leading cause of amputation in diabetic patients [5]. Ohsawa et al. [6] have found that skin thermography was one of the effective determinants of amputation level, in order to avoid reamputation.

The most frequently reported complication of diabetic foot is plantar ulceration. Primary risk factors of ulceration are loss of protective sensation and high plantar pressure. This complication that might lead to amputation at a later stage is preventable by comprehensive screening examination and patient education (foot care). However, if infected and progression occurs along the fascial planes, limb amputation may be the end result. Inadequate diabetic control increases the chances of complications in diabetes.

Complications like vision loss may lead to increased chances of injuries and delayed detection of foot ulcers especially in presence of sensory loss. Autonomic neuropathy and presence of scar due to previous ulceration and operations produce dry and noncompliant skin that predisposes to ulceration. Data on exact incidence of injuries leading to ulceration in diabetes is difficult to find. Fifteen percent of diabetic patient experience ulcerations over foot and ankle. The incidence of gangrene (a possible sequela of ulceration) is 4.5 cases per 1000 diabetic patients [7].

Neuropathy, angiopathy, skin changes (cracks), callosities, and foot deformities leads to nonhealing ulcers followed by infection [8]. Non healing ulcers and infection are major reasons for progressive tissue destruction in diabetic patients. Repeated radical debridement leads to loss of certain amount of viable tissue exposing vital structure, bone, ligaments and subsequent desiccation of exposed tissues and infection starts a vicious cycle of debridement and further tissue destruction leading to amputation.

Control of diabetes, daily inspection, foot care, proper definitive footwear with appropriate modifications and immobilization in selected cases of neuropathic fractures help in preventing the foot related complications. 
Page 2 of 5

Once ulcerations occur proper wound care and antibiotics helps to stop tissue destruction, spread of infection and promote wound healing. Newer dressing techniques like moist wound dressings and negative pressure dressing [9] methods are known to reduce and treat infection, and hasten healing. Since LAD combines principles of both moist wound dressing and negative pressure dressing with some extra advantages over both these methods, it offer a consistent and better chance of limb salvage. Negative pressure of LAD along with placement of drains in infectesfascial planes of foot (concept of target tissue [10]) and leg helps to stop the spread of infection along fascial/ peritendinous planes.

The author of the present article has done more than 2000 LAD for all types of acute and chronic wounds (including burn, trauma, necrotising fasciitis, gangrene, diabetic foot, carbuncles, post-operative to prevent surgical site infection in diabetic patients, postoperative wound dehiscence, exposed implants including synthetic vascular grafts and pacemakers, post fasciotomy and escharotomy wounds, sternotomy wound dehiscence after open cardiac surgery, abdominal wall reconstruction etc.) after designing LAD more than one decade back. On several occasions the patients with advice for foot and leg amputation by at least one general surgeon and one orthopedic surgeon, were successfully treated by LAD as a last try to salvage the limb. At present exact figure about success in treating such cases is not available.

In the present article the author intends to describe basic principle of LAD, method of application over foot and leg, effectiveness and reliability of LAD for diabetic foot salvage and its edge over other available alternatives.

\section{Basic Principle and Design of LAD}

NPWT has been shown to be a safe and effective treatment for complex diabetic foot wounds [9]. LAD has been designed to reduce the pain and discomfort of conventional dressings, to reduce the frequency of dressing, to reduce the chances of wound infection and to improve the results obtained by negative pressure dressing [10-12].

LAD combines the principles of moist wound healing and NPWT along with a provision of two additional ports (1216Frtube) for instilling antimicrobial solution of choice and alters the wound environment without any need to change the dressing. LAD utilizes definite intermittent negative pressure schedule (30 minutes of negative suction and $3 \frac{1}{2}$ hours of rest i.e. no suction period; minimum $30 \mathrm{mmHg}$ of negative pressure).

\section{Method of Application of LAD}

For applying LAD over extremity wounds [10-12] (Figure 1), either ethylene oxide presterilized customized polythene bag are used or based on the shape, size and site of the wound customized polythene bag is sealed using semi automatic plastic sealing machine and sterilized by immersion in $2.45 \% \mathrm{w} / \mathrm{v}$ glutaraldehyde solution for 20 minutes. Two thick nasogastric tubes (extra holes are made if required) after placed in between the bag and wound are brought out through the polythene cover at the predetermined site. The junction between tubes and polythene is sealed using hydrocolloid material and electrical insulation tape. Now at the mouth of the bag, the edges of polythene are sealed over extremity skin using hydrocolloid material and polyurethane film. Now, the tubes are connected to the suction machine using a Y connection.

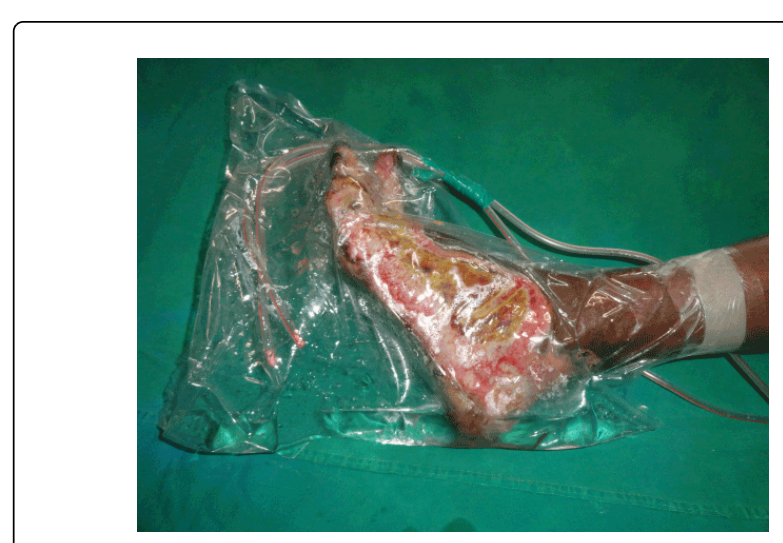

Figure 1: Photograph showing Limited Access Dressing for foot wound

\section{LAD as an Effective and Reliable Tool for Limb Salvage}

LAD is a reliable and effective method of limb salvage in diabetic cases by virtue of better control of infection, SIRS, minimizing deformity (by early physiotherapy), better acceptance because of various advantages over other modern methods of dressings and ultra conservative debridement (minimal damage to viable tissue by safer intra LAD natural separation of necrotic tissue).

\section{Intermittent negative pressure of LAD controls SIRS and organ failure}

In a preliminary study [10] (August 2005, September 2007 at Burns ward Kasturba Medical College, Manipal) to prove leech effect two identical groups of 54 thermal burns (less than $48 \mathrm{hrs}$ duration) patients were made: Control group and LAD treated group each comprising of 27 extremities burn matching in age, sex and TBSA burn. There was no statistically significant difference in occurrence of SIRS on Day 1 (control group 26 vs LAD group 23; p value 0.742 ), but on Day 5 the difference in occurrence of both SIRS (control group 18 vs LAD group 23, p value 0.029) and occurrence of organ Dysfunction (control group 12 vs. LAD group 4; p value 0.017 ) was significant. To alleviate the greater risk, odd ratio was analysed. The difference between two groups in SIRS on Day 1 was not significant, but on Day 5 was significant $(\mathrm{p}<0.05)$. The difference in organ dysfunction on Day 5 between two groups was also significant $(\mathrm{p}<0.05)$.

\section{Role of LAD in preventing and treating wound infection}

\section{Negative pressure helps to eradicate the established infection}

LAD is very effective in eradicating both gram positive (100\%) and gram negative bacteria $(98.74 \%-100 \%)$. In post LAD period by 7 th day surface swab shows growth of gram negative bacteria in $5057.14 \%$ cases [13]. This may be explained by contamination during LAD wash/ through leak site LAD device. LAD is effective to prevent wound infection by these bacteria.

The efficacy of LAD in eradication of resistant bacterial infections [10], was studied (2010; unpublished) on 60 patients with one or more wounds. Out of 60 patients, in 57 (95\%) patients bacterial growth was detected, treatment with LAD for 10 days resulted in no growth in $34 / 57$ (59.6\%) patients, and reduction in the number of organisms in 
Page 3 of 5

19/57 (33.33\%) patients. Identification and antibiotic susceptibility was done using CLSI (Clinical Laboratory Standard Institute, USA) guidelines. The strains were checked for multidrug resistant enzyme production using disk approximation method and biofilm formation ability was tested using microtitre well method.

Among isolates $(\mathrm{n}=93)$ from the preLAD samples: biofilm producers were 35(37.6\%), Extended Spectrum Beta Lactamase producers (ESBLs) 24(25.4\%), AmpC beta lactamases producers 8(8.6\%), Metallo Beta Lactamase (MBL) producers 17 (18.2\%). A total of 52 multidrug resistant organisms were isolated; out of which 8 did not produce any of the above enzymes.

Among isolates $(\mathrm{n}=26)$ from the 10 days postLAD samples: Biofilm producers were in 2(7.6\%), ESBL 6(23.07\%), AmpC 4(15.38\%) and MBL 5(19.2\%). A total of 15 multidrug resistant organisms were isolated; out of which 4 did not produce any of the above enzymes.

\section{Negative pressure reduces the chances of wound invasion}

Negative pressure by providing channels with stronger negative pressure towards suction bottle as compared to that in venules and lymphatics, reduces the chances of wound invasion by colonized microorganisms and spreading of infection along with fascial planes/ sloughing tendons.

\section{Intermittent negative pressure of LAD controls infection effectively}

Surgeons believe that without topical or systemic antimicrobial cover wound remains contaminated for 68 hours after wounding. All other events related to infection occur after 68hours (Table 1). Negative pressure applied every 4 th hourly for $1 / 2$ hour ( $1 / 2$ hour suction and $3 \frac{1}{2}$ hour no suction period) reduces chances wound invasion/ SIRS/sepsis/severe sepsis/ organ dysfunction and failure.

\begin{tabular}{|c|c|c|c|}
\hline $\begin{array}{l}\text { Duration after } \\
\text { wounding (without } \\
\text { antimicrobial } \\
\text { treatment) }\end{array}$ & Events & Outcome & Role of LAD \\
\hline$<6-8 \mathrm{hrs}$ & $\begin{array}{l}\text { Environment microorganisms reach } \\
\text { over the wound }\end{array}$ & Wound contamination & $\begin{array}{l}\text { Barrier by polythene and aseptic } L A D \text { wash using } \\
\text { negative pressure reduces chances of contamination }\end{array}$ \\
\hline $6-8 \mathrm{hrs}$ & $\begin{array}{l}\text { Microorganisms starts growing over } \\
\text { the wound }\end{array}$ & $\begin{array}{l}\text { Wound colonization, } \\
\text { production harmful bacterial } \\
\text { enzymes/toxins } \\
\text { and formation of biofilm may start }\end{array}$ & $\begin{array}{l}\text { LAD wash and intermittent negative pressure every } \\
4 \text { th hourly reduces chances of colonization, removes } \\
\text { harmful chemicals and breaks biofilm barrier }\end{array}$ \\
\hline After 6-8 hrs & $\begin{array}{l}\text { Microorganisms start } \\
\text { invading the viable } \\
\text { tissue }\end{array}$ & $\begin{array}{l}\text { Wound invasion/wound } \\
\text { sepsis (rapidity of } \\
\text { invasion depends on quantitative } \\
\text { bacterial count and virulence) }\end{array}$ & $\begin{array}{l}\text { Intermittent negative pressure every } 4 \text { th hourly } \\
\text { reduces chances of invasion by reducing count and } \\
\text { providing alternate stronger negative draining channel } \\
\text { to lymphatics and venules }\end{array}$ \\
\hline Late events & $\begin{array}{l}\text { A. Proinflammatory } \\
\text { cytokines produced in the wound is } \\
\text { absorbed in systemic circulation } \\
\text { B. Microorganism gains access to } \\
\text { circulation } \\
\text { C. Bacteria starts proliferating in } \\
\text { systemic circulation } \\
\text { D. Hypotension Produced } \\
\text { E. Organ functions deranged }\end{array}$ & $\begin{array}{l}\text { SIRS } \\
\text { Bacteremia } \\
\text { Sepsis } \\
\text { Severe sepsis } \\
\text { Organ dysfunction/ } \\
\text { Failure }\end{array}$ & $\begin{array}{l}\text { Leech effect of LAD reduces chances of SIRS and } \\
\text { organ failure (continuous suction } \\
\text { may be done if required) (Bacteria may gain access to } \\
\text { systemic circulation through other route e.g. bacterial } \\
\text { translocation, urinary } \\
\text { tract, cheat infection) }\end{array}$ \\
\hline
\end{tabular}

Table 1: Role of intermittent (4th hourly) negative pressure of LAD in wound infection

\section{Wound isolation}

Wound isolation by LAD polythene reduces the chance of bacterial colonization. Access of the microorganisms of the environment to the wound is limited by two long tubes and vice versa.

\section{LAD wash}

LAD wound wash with saline and removal of the wash fluid through the tubes reduces bacterial count over the surface and helps to prevent invasion.

\section{LAD produces ultra conservative debridement}

Following necrosis, the natural process of proliferation of living tissue and separation of necrotic tissue leaving viable proliferating cells in wound bed results in minimal or no loss of viable tissue as compared to surgical debridements. During the period of auto separation of dead tissue from living tissue, unfavorable wound environment may produce SIRS and infection. These complications (SIRS, infection, sepsis) are controlled by LAD satisfactorily. Hence, though time consuming, debridement under LAD is ultraconservative as in the process there occurs minimal or no loss of viable tissue. Intra LAD ultraconservative debridement occurs in two ways [14]: 
Page 4 of 5

- By phagocytosis and body enzymes in a moist environment. Viable cells proliferate and dead cells areshed.

- Mechanical debridement occur during suction and LAD wash

Slow autoseparation of necrotic tissue (time consuming) may be useful method to protect underlying structures (e.g. tendons over dorsum of foot/hand). Ultra conservative debridement conserves viable tissue maximally and hence LAD helps in diabetic foot salvage.

\section{Advantages of LAD}

Limited access dressing retains all the advantages of moist wound healing and negative pressure dressings [10].

\section{The edge of LAD over other moist healing dressing is:}

- The pus like gel (usually a source of concern to the patients in hydrocolloid dressings) produced due to dissolved hydrocolloid material is not a problem in LAD.

- Foul smell of moist dressing is reduced considerably due to LAD wash.

- Weak and limited absorbent capacity of moist dressing material is replaced by removal of secretion in an outside container by negative pressure that can be repeatedly replaced.

- Anaerobic growth is not a problem.

All the advantages negative pressure dressing is retained. Like other negative pressure dressings, consistently better graft take under LAD appears to be due to control of infection and compressions of graft between polythene sheet and recipient area. High levels of Vascular Endothelial Growth Factor (VEGF) associated with negative pressure dressing may also be responsible for better graft take [15]. The average number of days required to prepare the wound bed under LAD is much less as compared to that in conventional dressing. Overall graft take under LAD was $99.87 \%$ [13].

\section{The edge of LAD over other negative pressure dressing: Additional advantages over other negative pressure dressing methods are:}

- Intermittent low negative pressure makes LAD more acceptable and economical.

- Throughout treatment wound remains visible through polythene.

- Epithelialization is better than other negative pressure dressings where sponge is used

- Wound environment manipulation is possible in a variety of ways [16-18] (LAD wash, instillation of desired drug at desired site, aerobic/ anaerobic environment/ phototherapy).

- Since LAD is retained over the wound for a longer period, problems due to movements associated with frequent change of dressing in cases of compound fractures is avoided and makes it more suitable for compound comminuted fracture cases where early frequent dressings are required.

- Through transparent plastic sheet wound visibility is better.

- While hand/foot is still in LAD, physiotherapy (early) may be started.
- Intermittent negative pressure with the LAD may reduce the need for DVT prophylaxis [19] in immobilized patients with lower extremity wounds.

\section{Disadvantages of LAD}

LAD has following disadvantages that can be easily avoided by routine careful monitoring the progress of wound by an experienced person [20].

- Undesirable effects of negative pressure (pain, bleeding, ulceration)

- Ineffective negative pressure may invite undesirable effect of negative pressure (bad odor, anaerobic infection)

\section{Conclusion}

LAD is a safe, economic and effective alternative to conventional dressing method. It combines principles of both moist and negative pressure dressing. It follows a definite intermittent negative pressure regimen. It can be applied to all kind of wound irrespective of size, phase of wound healing and soakage. It not only tackles disadvantages of both negative pressure dressing and moist wound dressing, but has certain extra advantages over both methods. It improved the success rate following skin grafting (Final wound closure). It is an effective method for limb salvage for both acute and chronic wounds.

\section{References}

1. Most RS, Sinnock P (1983) The epidemiology of lower extremity amputations in diabetic individuals. Diabetes Care 6: 87-91.

2. Boulton AJ, Vileikyte L, Ragnarson-Tennvall G, Apelqvist J (2005) The global burden of diabetic foot disease. Lancet 366: 1719-1724.

3. Federation ID (2005) Put feet first: Prevent amputations. Chennai: International Diabetes Federation.

4. Bharara M, Mills JL, Suresh K, Rilo HL, Armstrong DG (2009) Diabetes and landmine-related amputations: a call to arms to save limbs. Int Wound J 6: 2-3.

5. American Diabetes Association (2003) Peripheral arterial disease in people with diabetes. Diabetes Care 26: 3333-3341.

6. Ohsawa S, Inamori Y, Fukuda K, Hirotuji M (2001) Lower limb amputation for diabetic foot. Arch Orthop Trauma Surg 121: 186-190.

7. Sims DS Jr, Cavanagh PR, Ulbrecht JS (1988) Risk factors in the diabetic foot. Recognition and management. Phys Ther 68: 1887-1902.

8. Rowe VL, Kaufman JL, Talavera F (2012) Diabetic Ulcers.

9. Armstrong DG, Lavery LA; Diabetic Foot Study Consortium (2005) Negative pressure wound therapy after partial diabetic foot amputation: a multicentre, randomised controlled trial. Lancet 366: 1704-1710.

10. Kumar P (2012) Exploiting potency of negative pressure in wound dressing using limited access dressing and suction-assisted dressing. Indian J Plast Surg 45: 302-315.

11. Kumar P (2009) Limited Access dressing and Maggots. Wounds 21: 150-152.

12. Kumar P, Sharma A (2010) Limited Access dressing for damage Control in trauma patients. Wounds 22: 188-192.

13. Kumar P (2008) Limited Access Dressing. Wounds 20: 49-59.

14. Sieggreen MY, Maklebust J (1997) Debridement: choices and challenges. Adv Wound Care 10: 32-37.

15. Téot L, Otman S, Hussenet P, Moles J (2000) Expression of angiogenic factors in chronic wounds treated with negative pressure therapy. The 10th Annual Meeting of the European Tissue Repair Society, May, Brussels, Belgium. 
16. Rao BK, Kumar P, Rao S, Gurung B (2011) Bactericidal effect of ultraviolet C (UVC), direct and filtered through transparent plastic, on gram-positive cocci: an in vitro study. Ostomy Wound Manage 57: 46-52.

17. Prabhu V, Rao SB, Rao NB, Aithal KB, Kumar P, et al. (2010) Development and evaluation of fiber optic probe-based helium-neon low-level laser therapy system for tissue regeneration--an in vivo experimental study. Photochem Photobiol 86: 1364-1372.

18. Prabhu V, Rao SB, Rao NB, Aithal KB, Kumar P, et al. (2010) Development and evaluation of fiber optic probe-based helium-neon low-level laser therapy system for tissue regeneration--an in vivo experimental study. Photochem Photobiol 86: 1364-1372.

19. Hegde VN, Prabhu V, Rao SB, Chandra S, Kumar P, et al. (2011) Effect of laser dose and treatment schedule on excision wound healing in diabetic mice. Photochem Photobiol 87: 1433-1441.

20. Urbankova J, Quiroz R, Kucher N, Goldhaber SZ (2005) Intermittent pneumatic compression and deep vein thrombosis prevention. A metaanalysis in postoperative patients. Thromb Haemost 94: 1181-1185. 